\title{
Presence of anti-Toxoplasma antibodies in humans and their cats in the urban zone of Guadalajara
}

\author{
Presencia de anticuerpos anti-toxoplasma en humanos y sus \\ gatos, en la zona urbana de Guadalajara \\ María de la Luz Galván Ramírez, Guillermo Sánchez Vargas, \\ Marcos Vielma Sandoval and Juan Luis Soto Mancilla
}

\begin{abstract}
Cats are the definitive hosts of Toxoplasma gondii. Infected cats excrete oocysts in their feces, infecting humans and other animals. The objective of the present study was to determine the presence of anti-Toxoplasma antibodies in cat owners and their pets, and determine if there was a relationship between Toxoplasma infection and humans who live with infected cats. IgG anti-Toxoplasma antibodies in sera of 59 cat owners were determined by enzyme-linked immunosorbent assay (ELISA), in 24 sera from their cats, $\lg G \lg M$, and $\lg A$ antibodies were found using Burney's ELISA. Thirty-eight (64\%) of 59 cat owners were positive to IgG antiToxoplasma. Seropositivity for cats was $70.8 \% \lg$ G, $8.3 \% \lg M$, and $62.5 \% \lg A$. Cohabitation with cats infected by T. gondii, feeding with leftovers or raw viscera, and lack of control over how their feces were handled are risk factors conducive for humans to become infected by T. gondii.
\end{abstract}

Key-words: Toxoplasmosis. Antibodies. Humans. Cats. Elisa.

Resumen Los felinos son huéspedes definitivos de Toxoplasma gondii. Los gatos infectados excretan ooquistes en sus heces, infectando a humanos y a otros animales. El propósito de este estudio fue determinar anticuerpos anti-Toxoplasma en dueños de gatos y sus mascotas y conocer si existía relación entre la infección por Toxoplasma en humanos que conviven con gatos infectados. Se determinaron anticuerpos anti-Toxoplasma Ig $\mathrm{G}$ en 59 sueros de dueños de gatos por el método de ELISA (Sigma), y en 24 sueros de sus gatos anticuerpos IgG, IgM e IgA por ELISA de Burney. Los dueños de gatos fueron positivos a IgG anti-Toxoplasma 38/59 64\%. La seropositividad de gatos fue de $70.8 \% \lg$ G, $8.3 \%$ a $\lg M$ y $62.5 \% \lg A$. Cohabitar con gatos infectados por T. gondii dentro del hogar, alimentarlos con desechos de mesa o vísceras crudas y la falta de control de sus heces son factores de riesgo para adquirir infección por T. gondii en el humano.

Palabras-claves: Toxoplasmosis. Anticuerpos. Humanos. Gatos. Elisa.

Toxoplasmosis is a disease caused by an obligate intracellular parasite called Toxoplasma gondii whose definitive hosts are cats; warmblooded animals, including man, are its intermediate hosts ${ }^{18}$. Infected cats' oocysts in feces, create a risk factor for the infection of other animals and human beings, encouraging the development of toxoplasmosis ${ }^{7814}$. The seroprevalence in humans varies, depending on the geographic area and alimentary habits, it ranges from $7 \%$ to $90 \%{ }^{17}$; and in Mexico has been reported to range from $15 \%$ to $50 \%$ in an open population ${ }^{1316}$.

This work's aim is to determine the presence of anti-Toxoplasma gondii antibodies in humans and their cats, and to study the relationship between Toxoplasmosis and humans living with cats.

Center for Tropical Disease Research of the University of Guadalajara, Guadalajara, Jalisco, México.

Address to: Dr. María de la Luz Galván Ramírez. Lago Camécuaro 2398 Col. Lagos del Country C.P. 44281 , Apartado Postal 2-816. Guadalajara, Jalisco, Mexico.

Tel: (523) 618-8527; Fax: (523) 618-14-24.

E-mail: mgalvan@irsp.dsp.udg.mx

Recebido para publicação em 9/6/97. 


\section{MATERIAL AND METHODS}

This is a cross-sectional, random study of a cohort, performed from April to June 1995, choosing 59 subjects living with cats. The study group was made up of adult subjects from metropolitan Guadalajara, Jalisco, Mexico, living in 20 randomly chosen city blocks.

Criteria for being included. Humans. Subjects between 15 and 81 years old who had lived with cats for a minimum period of 6 months, and who agreed to participate in the study, were chosen.

Cats. Twenty-four cats that were donated by their owners, all of them seropositive to IgG antiToxoplasma antibodies, were included.

Variables. Humans. Age, sex, IgG antibodies.

Cats. Habitat (living indoors at owner's home or outdoors), method of handling feces (with or without control), type of food (viscera, table leftovers, and dry food), and $\lg G, \lg M$, and $\lg A$ anti-Toxoplasma antibodies.

Enzyme-linked Immunosorbent assay (ELISA). The presence of IgG anti-Toxoplasma antibodies in the blood samples of these patients was assayed using the ELISA (Sigma Diagnostic, PO Box 14508 St Louis, MO 63178 USA). The absorbency values for seropositivity considered were: $<0.21-0.33$ low positive; 0.34-0.64 medium positive, and $<0.65$ high positive.

Cats. Twenty-four serum samples of the cats of seropositive patients were studied. IgG, IgM, and IgA anti-Toxoplasma antibodies were identified using ELISA, as described by Burney and Lappin ${ }^{4}$.

Statistical analysis. Averages and standard deviations of the variables are presented; seropositive and seronegative humans were compared regarding the variable of living with a cat and the rest of the variables analyzed, rejecting the null hypothesis with an alfa significance of 0.05 . Analyses were performed through quadruple tables by the chi-square test and Fisher's exact probability, using the statistical computer program EPI 6 of the CDC of Atlanta, Georgia.

\section{RESULTS}

Humans. The ages of the 59 subjects included in the study ranged from 15 to 81 with an average of $44.9 \pm 17.3$ years; $22(37.38 \%)$ were male and $37(62.72 \%)$ females. It was found that 38 $(64.4 \%)$ were seropositive to IgG anti-

Toxoplasma antibodies. The majority of the positives showed high levels of I $\mathrm{gG}$ antiToxoplasma antibodies; their distribution according the level of antibodies is shown in Figure 1.

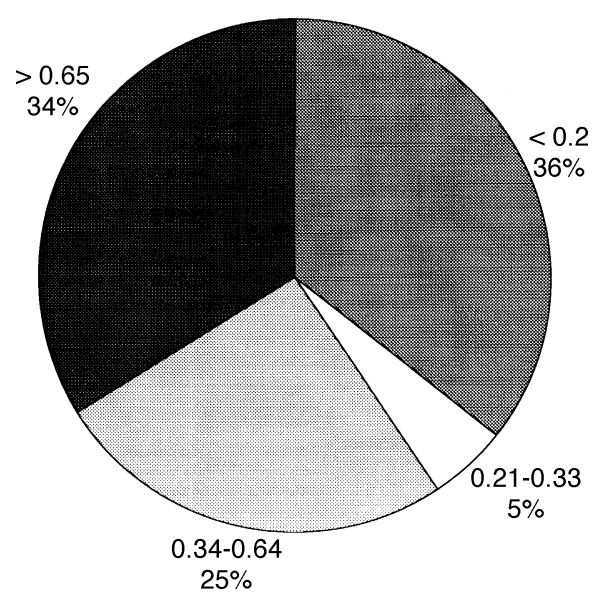

Figure 1 - Levels of anti-Toxoplasma antibodies in samples of sera of humans who own cats, using ELISA (Sigma). Negative value of SIA $<0.20 ; 0.21-0.33$ Low positive; 0.34 0.64 Medium positive; $>0.65$ High positive.

Among humans living with their cats, it was found that 45 kept them within the home and 14 outdoors; of the former, $32 / 45(71 \%)$ were seropositive and $13 / 45$ (28.9\%) seronegative; out of those who kept their cat outdoors, $6 / 14$ (42.8\%) were seropositive and 8/14 (57.2\%) seronegative. 
When comparing these results it was found that $\mathrm{p}=0.05$ (Figure 2).
Regarding the handling of cat feces, we found that only 7 owners had control over them and

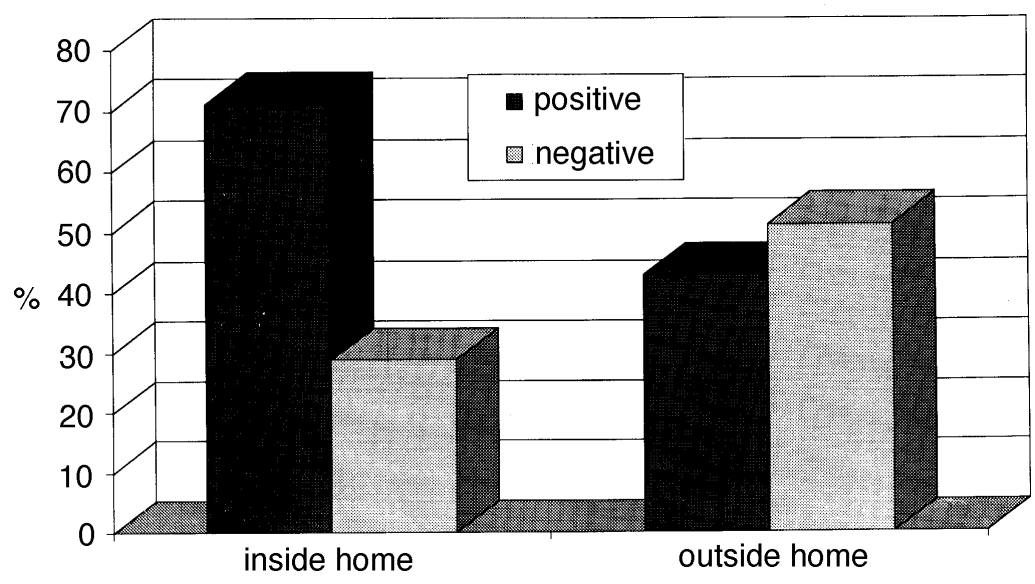

Figure 2 - IgG anti-Toxoplasma antibodies (ELISA) in humans related to the habitat of their cats; positives vs negatives living inside or outside the home (Fisher's test $p=0.05)$.

that 52 had no control. Among the former, 3/7 $(42.8 \%)$ were seropositive and $4 / 7(57.1 \%)$ seronegative; among those who had no control over feces, $35 / 52(67.3 \%)$ were seropositive and
$17 / 52(32.7 \%)$ seronegative. When we compared seropositive and seronegative with or without feces control by Fisher's exact test, we found a value of $p=0.1963$ which was not significant (Figure 3).

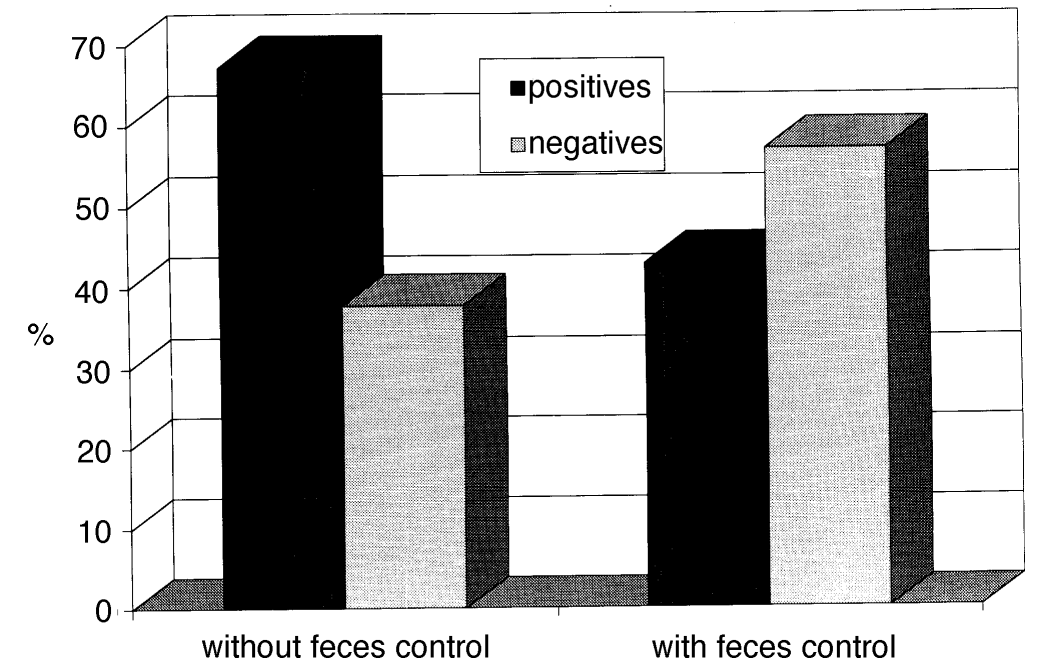

Figure 3 - IgG anti-Toxoplasma antibodies in humans in relation to the control of their cat's feces. Fisher's test, without feces control vs with feces control $p=0.1963$ (NS). 
Cats. In another part of the study, using serum from 24 cats from seropositive subjects, we found IgM anti-Toxoplasma antibodies in only 2 (8.3\%), $\lg \mathrm{A}$ in $15(62.5 \%)$, and $\lg \mathrm{G}$ in 17 (70.8\%). The titers for anti-Toxoplasma antibodies are shown in Table 1.

Table 1 - Titers of anti-Toxoplasma antibodies in cats using ELISA.

\begin{tabular}{lccc}
\hline Case & IgM & $\lg$ & IgA \\
\hline 6 & - & - & - \\
13 & - & 128 & 128 \\
14 & - & 64 & - \\
17 & - & 256 & 256 \\
18 & 256 & 2048 & 512 \\
22 & - & 512 & 128 \\
24 & - & 256 & 128 \\
31 & - & 512 & 128 \\
32 & 2048 & - & - \\
35 & - & - & - \\
42 & - & 512 & 512 \\
45 & - & 256 & 128 \\
47 & - & - & - \\
49 & - & - & - \\
50 & - & - & - \\
51 & - & 512 & 256 \\
57 & - & 2048 & 1024 \\
58 & - & - & - \\
58 & - & 64 & 64 \\
59 & - & 256 & 128 \\
59 & - & 64 & 64 \\
59 & - & 64 & 64 \\
59 & - & 64 & - \\
59 & - & 64 & 128 \\
\hline
\end{tabular}

Case 58 with two cats; case 59 with five cats; (-) negative; $\operatorname{lgM}=$ immunoglobulin $\mathrm{M}$; $\lg G$ = immunoglobulin $\mathrm{G}$; $\lg \mathrm{A}=$ immunoglobulin $\mathrm{A}$; significant titers for $\lg M, \lg G$ and $\lg A \cdot 1: 64$.

In the study of the correlation between the kind of food given and IgG seropositivity in cats, we found that among those fed table leftovers $13 / 17(76.5 \%)$ were seropositive, those fed dry food 2/6 (66.6\%) were seropositive, and those fed viscera $2 / 4$ (50\%) were seropositive; no statistically significant differences were found between these groups (Figure 4).

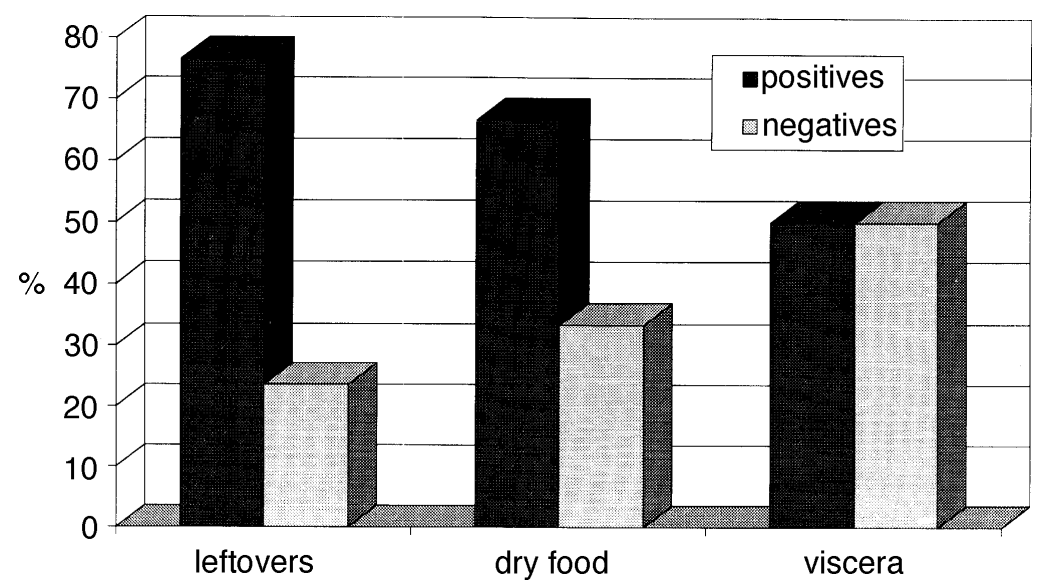

Figure 4 - IgG anti-Toxoplasma antibodies in humans related to the type of food eaten by their cats. Fisher's test, leftovers vs viscera, $p=0.3157$, leftovers vs dry food $p=0.6008$, and dry food vs viscera $p=0.6245$. 


\section{DISCUSSION}

We consider that for humans, to live with cats infected by $T$. gondii is a factor condusive to infection by Toxoplasma, since the proportion of seropositivity found in cat owners (0.64) is higher than in Jalisco's general population by IFI of $1: 16$ (.50) and 1:128 (.36) and in the Metropolitan Zone of Guadalajara (0.38) it is much lower; these results are similar to those obtained from studies done in other Mexican states ${ }^{217}$.

Among the risk factors for acquiring the infection, one is the type of living conditions that humans share with their cats that is, whether the infected animals are inside the home or not, since the former presented greater seropositivity, as already previously noted ${ }^{12617}$. These results give greater consistency to the previous affirmation.

The seropositivity to antibodies did not increase proportionally to the age of the patients, since it was higher in those more than 50 years old; however, since $50 \%$ were over 50 years old, we cannot infer from this study that the presence of antibodies increases with age, as shown in other populations ${ }^{17}$.

Regarding gender, the majority of the patients were females. This result differed from those of other investigations in which there were no differences in terms of sex ${ }^{15}$.
The elimination of oocysts in the feces of cats infected with T. gondii has been shown to be a transmission mechanism ${ }^{5}$; however, when comparing subjects who had or not, control over their cat's feces, there were no significant differences between seropositive and seronegative individuals, possibly because most of the cats were experiencing chronic infections in which oocysts are not eliminated in the feces so that this was not a decisive factor for transmission.

Primary infections shown by seropositives cats were scarce, since only two cases had IgM antibodies, the largest number (12), was positive for $\lg A$ antibodies, and 11 showed titers for $\lg G$ antibodies greater than 1:256; possibly these were more recent infections, as also shown by other researchers ${ }^{9}$; however, this cannot be clinically affirmed.

In Mexico there is no serological diagnostic practice to determine Toxoplasma infection in cats; therefore, it would be important to develop diagnostic methods to identify its antibodies in serum and aqueous humor of cats, making it possible to diminish infections in humans contaminated by their cats. It is essential to educate the population regarding handling of cats, including habitat, type of food and feces control; these factors should be controlled to reduce the infection in humans who share living quarters live with cats.

\section{REFERENCES}

1. Alluja AS, Aguilar P. Estudio sobre la frecuencia del ooquiste de Toxoplasma gondii en el gato doméstico del Distrito Federal. Gaceta Médica de México 113:455-459, 1977.

2. Armas BM, Alvarez RM, Acosta AG. Presencia de ooquistes de Toxoplasma gondii en heces de gatos y su correlación con la sroprevalencia de sus dueños procedentes de 4 municipios del valle de MoreliaQueréndaro, Michoacán, México. Resumen de XIII Congreso Nacional de Parasitología CONAPAR'98 Zacatecas, México p. 63, 1998.

3. Blood DC, Henderson JA, Radostits OM. Medicina Veterinaria. Editora Interameriana México,DF. $6^{\text {th }}$ edition, p. 973-976, 1987.

4. Burney, Lappin MR, Cooper CM, Spilker MM. Demostration of Toxoplasma specific immunoglobulina $A$ in the serum of cats. Americal Journal Veterinary Researchs 56:769-773, 1995.

5. DiGiacomo RF, Harris NV, Huber NI, Cooney MK. Animal exposures and antibodies to Toxoplasma gondii in a university population American Journal Epidemology 131:129-133, 1990.
6. Dubey JP. Toxoplasmosis. Journal American Veterinary Medicine Association 205:1593-1598,1994.

7. Frenkel J. Toxoplasmosis parasite life cycle pathology and immunology. In: Hammond DM, Long LPL. The Coccidea: Eimeira, Isospora, Toxoplasma, and Related Genera. Baltimore University Park Press p.343-410, 1973.

8. Frenkel JK, Ruiz A, Chinchilla M. Soil survival of Toxoplasma oocysts in Kansas and Costa Rica. The American Journal Tropical Medicine and Hygiene 24:439443, 1975.

9. Galván RML, Soto MJL, Velasco CO, Perez MR. Incidence of Anti-Toxoplasma antibodies in women with high risk pregnancy and habitual abortions. Revista da Sociedade Brasileira de Medicina Tropical 28:333-337, 1995.

10. Lappin MR, Greene CE, Prestwod AK Donal L, Dawe, Tarleton R. Enzyme-Liked immunosorbent assay for the detection of circuating antigens of Toxoplasma gondii in the serum of cats. American Journal Veterinary Research 9:1586-1590, 1989. 
11. Lappin M, Greene C, Winston S, Toll SL, Epstei ME. Clinical Feline Toxoplasmosis. Jorunal of Veterinary Internal Medicine 3: 139-143, 1989.

12. Lappin MR, Roberts S, Davison M, Powell C, Reif J. Enzyme' liked immunosorbent assays for the detection of Toxoplasma gondii specific antibodies and antigens in the aqueous humor of cats. Journal American Medical Association 201:1010-1016, 1992.

13. Roch E, Varela G. Diversos aspectos de la investigación sobre la toxoplasmosis en México. Resultados de 29.883 reacciones de Sabin y Feldman efectuados de 1953 a 1965. Revista de Salud Pública de México 26:31-49, 1966.

14. Swartzberg JE, Remington JS. Transmission of Toxoplasma. American Journal Diseases Children 29:777-779, 1975.

15. Tenter AM, Vietmeyer C, Johnson AM, Janitseck K, Rommeln M. ELISA's based on recombinant antigens for seroepidemiological studies on Toxoplasma gondiii in cats. Veterinary Immunology Immunopathology 33:29-36, 1993.

16. Varela G, Molina PC, Sánchez BJ, Aluja AS. Toxoplasmosis: estudios de sueros humanos en los últimos 4 años. Comparación entre la serología de la toxoplasmosis y de la infección por sarcoides en bovinos. Revista de Investigación en Salud Pública de México 32:138, 1972.

17. Velasco O, Salvatierra IB, Valdespino JL, Sedano LA, Galindo VS, Magos C, Llausas A, Tapia R, Gutierrez G, Sepulveda J. Seroepidemología de la toxoplasmosis en México. Salud Pública de México 34:222-229, 1992.

18. Wong SY, Remington JS. Biology of Toxoplasma gondii. AIDS 7:299-316, 1993. 